\title{
MITIGATION OF METHANE EMISSION FROM RICE FIELDS USING DIFFERENT NITROGEN TYPES AND RICE VARITIES
}

\author{
EL-Kassas, H. I. ${ }^{(1)}$; A, Razek, T. M. ${ }^{(1)}$; Hassanein, M. K. ${ }^{(2)}$ \\ and Srour, Hanan, $M$. \\ 1) Institute of Environmental Studies and Research, Ain Shams University \\ 2) Field crop Research Institute, Agriculture Research center
}

\begin{abstract}
An experimental study was conducted to investigate the effect of different nitrogen fertilizers and rice cultivars on $\mathrm{CH}_{4}$ emission from a rice paddy. The experiment was designed with two nitrogen fertilizer types, (ammonium sulfate and urea). Two rice cultivars (Giza 177 and Sakha106) were used for the plots experiment. Each experiment replicated triply. Methane flux was measured at different growth stages for the two rice cultivar treated with ammonium sulfate or urea fertilizer. There was significantly increase in methane emission fluxes due to plantation of $\mathrm{Sakha}_{106}$ rice as a comparison of two rice varieties, Moreover, ammonium sulfate treatment significantly reduced $\mathrm{CH}_{4}$ emissions by 50 to $55 \%$ emissions compared to urea plots, also results indicated that the combination of $\left(\mathrm{NH}_{4}\right)_{2} \mathrm{SO}_{4}$ application and sakha 106 rice. It was concluded that the $\mathrm{CH} 4$ emission was dependent on the type of nitrogen fertilizer and rice varieties in Egypt paddy soils.
\end{abstract}

Keywords: Methane, Rice fields, Emission, Global warming

\section{INTRODUCTION}

Global warming is one of the challenges facing human being. This is caused by increasing concentration of greenhouse gases emit to the atmosphere. Methane $\left(\mathrm{CH}_{4}\right)$ is the most abundant organic trace gas in 
atmosphere. That has a significant effect on atmospheric temperature and chemistry (Anitha and Bindu, 2016). The Inter-governmental Panel on climate change points out that methane has 25 times higher global warming potential over 100 year time-horizon as compared to $\mathrm{CO}_{2}$ (IPCC, 2007). Out of the anthropogenic sources rice paddies are considered a major source of methane $\left(\mathrm{CH}_{4}\right)$ emissions. Rice is one of the main food crops in many countries. $\mathrm{N}$ fertilizers may directly or indirectly affect all of the important processes involved in the $\mathrm{CH}_{4}$ budget of rice paddies, i.e. the production, oxidation and transport of $\mathrm{CH}_{4}$. However, studies investigating $\mathrm{N}$ fertilizer effects on these processes have yielded. For example, after fertilization with urea or $\left(\mathrm{NH}_{4}\right)_{2} \mathrm{SO}_{4}$, lower $\mathrm{CH}_{4}$ emissions were detected and attributed to the direct inhibition of methanogenesis (Ma et al., 2007). According to the IPCC (1996) there are several factors effect on the amount of methane emission from rice paddies. They are soil type and temperature, irrigation practices, duration and number of the harvest, rice species and fertilizer use. So, the objectives of this study are to investigating the effects of various nitrogen fertilizers and rice varieties on methane emission throughout the growth stages of rice from the paddy soils in Egypt, and to provide the data for estimation of the mitigation potentials in rice agricultural systems.

\section{MATERIALS AND METHODS}

1. Experimental site: Experimental paddy fields were located at the farm of CLAC (Central laboratory for Agricultural Climate), Agricultural Research Center (ARC), Dokki. Giza, Egypt, and the methane emission data were collected between May and September 2014. The soil characteristics were 
determined as follows: the physical and chemical characteristics of the soil were determined before planting (Table1). Soil mechanical was carried out by the international pipette methods (Piper, 1950) using sodium hexametaphosphate as a dispersing agent. Soil textural class was defined using the texture triangle diagram (Soil Survey Staff, 1962). Organic matter content was determined using the modified walkley and black method (Jackson, 1958). Soil $\mathrm{pH}$ was determined in 1:2:5 soil water extract using a glass electrode of Bechman apparatus (Richard, 1954). Electrical conductivity in 1:2:5 soil water extract were determined according to (Black et al., 1982).

Table (1): Some physical and chemical characteristics of the soil before planting.

\begin{tabular}{|c|c|c|c|c|c|c||}
\hline PH & \multirow{2}{*}{ EC ds $\mathbf{~ m}^{-1}$} & O.M. \% & \multicolumn{3}{|c|}{ Particle size distribution \% } & Textural \\
\cline { 4 - 6 } & & & Sand & Silt & Clay & class \\
\hline \hline 7.1 & 0.54 & 1.35 & $18.2 \%$ & $27 \%$ & $54.8 \%$ & alluvial \\
\hline
\end{tabular}

2. Rice varieties and nitrogen fertilizers: Giza ${ }_{177}$ and Sakha ${ }_{106}$ Japonica rice (Oryza sativa L.) were planted in 2014. A basal dose of phosphorus was applied at the rate of $\mathrm{P}_{2} \mathrm{O}_{5} 36 \mathrm{~kg} \mathrm{ha}^{-1}$ as triple super phosphate and $\mathrm{ZnSO}_{4}$ in dry soil before sowing the seed., nitrogen was split-applied as (urea) and (ammonium sulfate) at rate of $\mathrm{N} 96 \mathrm{~kg} \mathrm{ha}^{-1} 2 / 3$ of urea and ammonium sulfate was incorporated before irrigation and $1 / 3$ was applied at panicle initiation stage. There were four plots, plot A was Sakha ${ }_{106}$ rice and urea, plot B was Giza $_{177}$ rice and urea, plot C was Sakha ${ }_{106}$ rice and ammonium sulfate, plot D was Giza $_{177}$ rice and ammonium. Rice field operations were as follows: Plowing on 5May, Flooding on 18 May, Seeding on 20 May and harvesting on 
25 September in 2014 (total cultivation period of 125 days). Rice straw was removed from the field after harvest.

2.3. Measurement of methane flux: $\mathrm{CH}_{4}$ flux was determined during one in the noon at every growth stage using closed chamber technique (Yang and Chang, 1998). The chamber was made from wood structure covered with polyethylene sheet $\left(1 \mathrm{~m}^{3}\right)$ pushed into the soil approximately $7-15 \mathrm{~cm}$ depending on soil moisture content at the time of the sampling.

2.4 Analysis :Methane was measured by the Thermo Scientific Miran Sapphire Portable Ambient Analyzer from spaces in the chamber. The methane flux, F (mg m $\left.{ }^{-2} \mathrm{hr}^{-1}\right)$ was calculated (Marshall et al., 2010).

Statistical analysis: Treatments were replicated three times and flux data were subjected to analysis of variance and Duncan's multiple range test $(p=0.05)$ (Duncan 1955) using the Statistical Analysis System (SAS, 2010) version 9.1. Correlation of methane with other growth parameters was done by Pearson correlation method.

\section{RESULTS AND DISCUSSION}

Table (2): Methane emission during different rice growth stages, $\left(\mathrm{mg} \mathrm{m}^{-2} \mathrm{hr}^{-1}\right)$.

\begin{tabular}{|c|c|c|c|c|}
\hline Stages & $\begin{array}{c}\text { Sakha rice } \\
\text { (urea) }\end{array}$ & $\begin{array}{c}\text { Giza rice } \\
\text { (urea) }\end{array}$ & $\begin{array}{c}\text { Sakha rice } \\
\mathbf{( N H 4 )}_{2} \mathbf{S O}_{\mathbf{4}}\end{array}$ & $\begin{array}{c}\text { Giza rice } \\
\mathbf{( N H 4 )}_{2} \mathbf{S O}_{\mathbf{4}}\end{array}$ \\
\hline \hline Transplanting & $2.93 \pm 0.81^{\mathrm{d}}$ & $2.30 \pm 0.36^{\mathrm{d}}$ & $1.17 \pm 0.49^{\mathrm{d}}$ & $1.16 \pm 0.47^{\mathrm{d}}$ \\
\hline Tillering & $11.09 \pm 0.27^{\mathrm{b}}$ & $9.50 \pm 0.36^{\mathrm{b}}$ & $4.98 \pm 0.48^{\mathrm{b}}$ & $4.80 \pm 0.10^{\mathrm{b}}$ \\
\hline Booting & $5.49 \pm 0.50^{\mathrm{c}}$ & $4.73 \pm 0.64^{\mathrm{c}}$ & $2.60 \pm 0.10^{\mathrm{c}}$ & $2.45 \pm 0.05^{\mathrm{c}}$ \\
\hline Flowering & $38.00 \pm 1.00^{\mathrm{a}}$ & $30.06 \pm 11.22^{\mathrm{a}}$ & $15.00 \pm 1.00^{\mathrm{a}}$ & $14.00 \pm 1.00^{\mathrm{a}}$ \\
\hline Ripening & $0.25 \pm 0.13^{\mathrm{e}}$ & $0.22 \pm 0.07^{\mathrm{e}}$ & $0.13 \pm 0.05^{\mathrm{e}}$ & $0.10 \pm 0.08^{\mathrm{e}}$ \\
\hline Average & $\mathbf{1 1 . 5 5}$ & $\mathbf{9 . 3 6}$ & $\mathbf{4 . 7 7}$ & $\mathbf{4 . 5 0}$ \\
\hline
\end{tabular}




\section{Effect of nitrogen fertilizer on methane emission}

Table3: Methane emission ( $\mathrm{mg} \mathrm{m}^{-2} \mathrm{hr}^{-1}$ ) as affected by two nitrogen fertilizers.

\begin{tabular}{||c|c||}
\hline Fertilizer & Mean \pm SD Methane Emission $\left(\mathbf{m g m}^{-2} \mathbf{h r}\right.$ \\
& -1 \\
\hline Urea & $10.45 \pm 12.94^{\mathrm{aA}}$ \\
\hline$(\mathbf{N H 4})_{2} \mathrm{SO}_{4}$ & $4.64 \pm 5.29^{\mathrm{aA}}$ \\
\hline Average & $\mathbf{7 . 5 4}$ \\
\hline
\end{tabular}

$\mathrm{N}$ - Fertilizers may directly or indirectly determined the amount of methane emission through three processes: $\mathrm{CH}_{4}$ production, oxidation, and transport from the soil to atmosphere that demonstrated by numerous previous studies (Cai et al., 2007., Banger et al., 2012 and Dong et al., 2011).

The positive effects of Ammonium-based fertilizer on methane emission were debated among research which is mainly attributed to inverse relationship between $\mathrm{NH}_{4}{ }^{+}$availability in the rice rhisosphere with methane emission where $\mathrm{CH}_{4}$ and $\mathrm{NH}_{4}^{+}$are similar in size and structure and as a result, $\mathrm{CH}_{4}$ monooxygenase (the enzyme that oxidizes $\mathrm{CH}_{4}$ ) bend and reacts with $\mathrm{NH}_{4}{ }^{+}$ instead of $\mathrm{CH}_{4}$ so $\mathrm{NH}_{4}{ }^{+}$prevents methane consumption. Chowdhury and Dick (2013). However, Palmer and Reeve (1993). reported that methanogens obtain a nitrogen source from $\mathrm{NH}_{4}{ }^{+}$. Furthermore, $\mathrm{NH}_{4}{ }^{+}$specially increasing both root growth that provide larger arenchyma acts as a channel for methane transport from rhisosphere to air space, and release of root exudates Linquist et al. (2012) that enhancing methanogenic activity and increase $\mathrm{CH}_{4}$ emission from soil .

Concerning the negative effect, $\mathrm{NH}_{4}{ }^{+}$ions stimulate activity of oxidizing bacteria (methanotrophs) leading to a reduction in emission as reported by Bodelier and Laanbroek (2004) .Also Yao et al. (2012). found that treatment 
with urea stimulates rice biomass could lead to higher combination between $\mathrm{NH}_{4}{ }^{+}$avability and $\mathrm{O}_{2}$ input by roots to soil enhanced methane oxidation.

Our objective was to determine at the field level the net effect of nitrogen fertilizer on methane emission. In the present study which included urea and ammonium sulfate application it is shown that ammonium sulfate reduce $\mathrm{CH}_{4}$ emission about 50-55 \% as compared by urea. Likewise this in contrast to studies supported by other worker as Kimura confirmed the advantage of $\left(\mathrm{NH}_{4}\right) \mathrm{SO}_{4}$ in reducing $\mathrm{CH}_{4}$ emission followed by ammonium chloride then urea. As well as Liou et al. (2003) observed the effect of ammonium sulfate on inhabitation methane emission as compered by potassium nitrate especially at the first crop season under title methane emission from fields with differences in nitrogen fertilizers and rice varieties in Taiwan paddy soils.

Also Lindau (1994) used several forms of $\mathrm{N}$ fertilizer (urea, $\left(\mathrm{NH}_{4}\right)_{2} \mathrm{SO}_{4}$, $\left.\mathrm{KNO}_{3}\right)$ to study the effect of them on $\mathrm{CH}_{4}$ emission at different loads $(0,60$ and $120 \mathrm{Kg} \mathrm{N} \mathrm{ha}^{-1}$ ). Results showed that urea application stimulate the highest $\mathrm{CH}_{4}$ emission, followed by $\mathrm{KNO}_{3}$ and then $\left(\mathrm{NH}_{4}\right)_{2} \mathrm{SO}_{4}$ in the low $\mathrm{N}$ rate. Cai et al. (1997) found that $\left(\mathrm{NH}_{4}\right)_{2} \mathrm{SO}_{4}$ reduced $\mathrm{CH}_{4}$ emission by $(50-60 \%)$ as compared to urea indicating that the form of nitrogen fertilizer strongly effects methane emission.

Hence the real reason for lower $\mathrm{CH}_{4}$ emission with ammonium sulfate in the present study is most likely due to addition of sulfate indicating that the type of nitrogen fertilizer affect $\mathrm{CH}_{4}$ emission. That in contrast with Pennock et al. (2010) who found that annual $\mathrm{CH}_{4}$ emission from a freshwater wetland declined when the concentration of $\mathrm{SO}_{4}^{-2}$ in the water increased, Segers (1998) 
summarized that the sulfate can reduced overall $\mathrm{CH}_{4}$ emission by both suppressing methanogensis to anaerobic $\mathrm{CH}_{4}$ oxidation.

Previous studies have shown that treatment rice field with sulfate fertilizers inhibited methane emission from rice fields (Gon et al., 2001).

Methane is the end product of a serious reduction process and sulfate are known as a strong competent with methanogens for $\mathrm{H}_{2}$ as a result inhibiting methane production when added to methanogenic rice fields Kluber and conrad. (1998). That matching with Sahrawat. (2004) who found that the activity of methanogens need a large availability from free electron which in turn increased the methane emission.

Three possible mechanisms for how sulfate (and other electron acceptors) could suppress methanogensis were proposed. First, the reduction of electron acceptors serves as an alternative to $\mathrm{CO}_{2}$ and leads to oxidation of organic matter thus could reduce substrate concentrations to a value that is too low for methanogenesis (Banger2012). Second, the presence of electron acceptors could result in a redox potential that is too high for methanogenesis. Third, the product of sulfate reduction (electron acceptors) could be toxic for methanogenic bacteria (Minami and Neue 1994).

Also in the present study results showed that urea specifically enhances yield and growth parameter (Table 4). However that's may be another reason for a significant increase in $\mathrm{CH}_{4}$ emission from urea applied plots.

From the previous results, it was concluded that the treatment (planting rice with ammonium sulfate) could probably a suitable strategy for methane mitigation for rice crop in Egypt. 
Table 4: The effect of fertilizer on growth characters and yield component for the two varieties at ripening.

\begin{tabular}{|l|c|c|}
\hline \multicolumn{1}{|c|}{ Production Parameters } & Urea (Mean \pm SD) & $\begin{array}{c}\text { Ammonium } \\
\text { sulphate(Mean } \pm \text { SD) }\end{array}$ \\
\hline Plant height (cm) & $99.36 \pm 3.19^{\mathrm{a}}$ & $95.41 \pm 0.75^{\mathrm{b}}$ \\
\hline No. of tiller & $26.80 \pm 1.18^{\mathrm{Ns}}$ & $25.83 \pm 1.06^{\mathrm{Ns}}$ \\
\hline No. of panicle & $24.95 \pm 1.79^{\mathrm{a}}$ & $22.75 \pm 1.15^{\mathrm{b}}$ \\
\hline Panicle length (cm) & $23.91 \pm 0.71^{\mathrm{a}}$ & $21.23 \pm 0.95^{\mathrm{b}}$ \\
\hline Panicle weight $(\mathbf{g})$ & $3.53 \pm 0.16^{\mathrm{a}}$ & $2.93 \pm 0.38^{\mathrm{b}}$ \\
\hline Dry root (g) & $7.35 \pm 0.47^{\mathrm{a}}$ & $5.82 \pm 0.22^{\mathrm{b}}$ \\
\hline 1000 Grain weight $(\mathbf{g})$ & $27.45 \pm 0.86^{\mathrm{Ns}}$ & $26.87 \pm 0.83^{\mathrm{Ns}}$ \\
\hline Root length $(\mathbf{c m})$ & $26.98 \pm 0.92^{\mathrm{a}}$ & $24.63 \pm 0.57^{\mathrm{b}}$ \\
\hline Straw yield (t/f) & $5.10 \pm 0.12^{\mathrm{a}}$ & $4.24 \pm 0.21^{\mathrm{b}}$ \\
\hline Grain yield (t/f) & $4.17 \pm 0.16^{\mathrm{Ns}}$ & $4.08 \pm 0.09^{\mathrm{Ns}}$ \\
\hline
\end{tabular}

2 The relation between type of fertilizer and growth characters: It was found that urea amendments significantly stimulate some of the measured rice plant and yield components in both varieties (Table 3 ). The yield components such as number of panicle, panicle length, Panicle weight, 1000grain weight and straw yield were increased significantly $(\mathrm{p}<0.05)$ by urea amendments(Table 4). The same results supported by Singh et al, (1999) who found that application of urea stimulate the growth and yield of rice.

Plant height and root growth parameters such as dry root and root length were significantly $(p<0.05)$ increased by urea amendments which were positively correlated with total seasonal methane emission (Table 2) That represents one of the causes of rising methane emissions from plots treated with urea. 
It is worth to be mentioned that Singh et al. (1999) found the response of different varieties to fertilization is varied indicating the differential resource employment prospect of the varieties when they studied methane emission and response of the three rice varieties to urea fertilization in India.

\section{CONCOLUTION}

$\mathrm{CH}_{4}$ emission from excessive planting rice in paddy fields can significantly contribute to global warming. The effects of $\mathrm{N}$-fertilizer and rice variety on methane emission were determined by static chamber method once every growth stages during the overall growing period as a way of the more feasible ways of limiting methane emission. Results indicated that combination of $\left(\mathrm{NH}_{4}\right)_{2} \mathrm{SO}_{4}$ application and sakha ${ }_{106}$ rice plantation is recommended for the benefit of both the environment (methane mitigation strategy) and the food security in Egypt paddy soil.

\section{REFERENCE}

Anitha, K and Bindu, G. (2016): Effect of controlled-released nitrogen fertilizer on methane emission from paddy field soil. Procedia Technology 24:196-202.

Banger, K.; Tian, H. and Lu, C. (2012): Do nitrogen fertilizers stimulate or inhibit $\mathrm{CH}_{4}$ emissions from rice fields? Global Change Biology. http:// dx. doi.org/ 10.1111/ j. 1365-2486.2012.02762.x.

Bodelier, P. L. and Laanbroek, H.J. (2004): Nitrogen as a regulatory factor of methane oxidation in soils and sediments FEMS Microbiol. Ecol. (47): 265-277.

Black, C.A.; D.D. Evans; J. I. White; L. E. Ensminger and F.E. Clark (1982): Methods of Soil Analysis, Amer. Soc. Agron. Inc. Madison, Wisconsin USA. 
Chowdhury, T. R and Dick, R. P. (2013): Ecology of aerobic methanotrophs in controlling methane fluxes from wetlands. Appl Soil Ecol (65):822 .

Cai, Z.; Shan, Y and Xu, H. (2007): Effects of nitrogen fertilization on CH4 emissions from rice fields. Soil Sci. Plant Nutr. (53):353-361.

Cai, Z.C.; Yan,X.Y.; Yan,G.;Xu,H.;Tsuruta, H.; Yagi, $\quad$ K. and Minami,K.(1997): Methane and nitrous oxide emissions from rice paddy fields as affected by nitrogen fertilisers and water management. Plant and Soil. (196):7-14.

Dong, H.B.; Yao, Z.S.and Zheng, X.H., (2011). Effect of ammonium-based, non-sulfate fertilizers on $\mathrm{CH}_{4}$ emissions from a paddy field with a typical Chinese water management regime. Atmospheric Environment (45): 1095-1101.

Duncon,D.B.(1955).The Multiple Ranges and multiple FTests.Biometrics, 11:1-42.

Gon, H.A.D.V.; Bodegom, P.M.V.; Wassmann, R.; Lantin, R.S.and MetraCorton, T.M. (2001): Sulfate-containing amendments to reduce $\mathrm{CH}_{4}$ emissions from rice fields: mechanisms, effectiveness and costs. Mitigation and adaptation strategies for global Change. (6):71-89.

Jakson, M.L. (1958): Soil Chemical Analysis. Englewood Cliffs, N. J.

IPCC 2007: Mitigation of climate change - contribution of Working Group III to the Fourth Assessment Report of the Intergovernmental Panel on Climate Change Cambridge, United Kingdom and New York, NY, USA: Cambridge University Press.

IPCC (1996): 'Agriculture- Methane Emissions From Rice Cultivation: Flooded Rice Fields', ch.4, pp.4.53-4.57.

Kluber, H.D. and Conrad, R. (1998): Effects of nitrate, nitrite, $\mathrm{NO}$ and $\mathrm{N}_{2} \mathrm{O}$ on methanogenesis and other redox processes in anoxic rice field soil. FEMS Microbial. Ecol. (25): 301-318. 
Linquest, B.A., Van Groenigen, K.J., Adviento-Borbe, M.A., Pittelkow, C.M., Van Kessel,C., (2012): An agronomic assessment of greenhouse gas emission from major cereal crops.Global change Biol.18,194209.

Liou,R,M.; Huang,S,N.and Lin,C,W.(2003): Methane emission from fields with differences in nitrogen fertilizers and rice varieties in Taiwan paddy soils. Chemosphere. (50): 237-246.

Lindau, C.W.(1994): Methane emissions from Louisiana rice fields amended with nitrogen fertilizers. Soil Biology and Biochemistry. (26): 353359.

Marshall,R.; Browell,D. and Smith,S (2010): 'Calculating rates of Emissions', Environment Agency, Environment Agency Guidance on Monitoring Landfill Gas Surface Emissions, 2010, LFTGN07 v2.

Ma, J.; Li,X.L.; Xu,H.;Han,Y.; Cai,Z.C. and Yagi,K. (2007): Effects of nitrogen fertilizer and wheat straw application on $\mathrm{CH}_{4}$ and $\mathrm{N}_{2} \mathrm{O}$ emissions from a paddy rice field.Australian Journal of Soil Research.( 45):359-367.

Minami, K.and Neue, H.U. (1994): Rice paddies as a $\mathrm{CH}_{4}$ source. Climate Change. ( 27):13-26.

Pennock, D.; Yates, T.;Bedard-Haughn, A.; Phipps, K.; Farrell, R. and Mcdougal, R.(2010): Landscape controls on $\mathrm{N}_{2} \mathrm{O}$ and $\mathrm{CH}_{4}$ emissions from freshwater mineral soil wetlands of the Canadian Prairie Pothole region. Geoderma. (155):308-319.

Palmer, R. R and Reeve, J. N. (1993): Methanogen genes and the molecular biology of methane biosynthesis. In: Sebald, M. (Ed.), Genetics and Molecular Biology of Anaerobic Bacteria. Springer Verlag, Berlin, pp. 13-35.

Piper, C. S. (1950): Soil and Plant Analysis, Inter. Sci. Publication, Inc. New york, USA.

Richard, L.A. (1954): Diagnosis and Improvement of Saline and Alkaline Soil. Handbook No.60, U.S.Dept. Agriculture.

SAS, (2010).SAS User's Guide: Statistics. Version 9.1.SAS Inst.Inc. Cary, NC., USA. 
Sahrawat, K.L. (2004): Terminal electron acceptors for controlling methane emissions from submerged rice soils. Comm. Soil Sci. Plant Anal. 35 (9-10), 1401-1413.

Singh. S.; Singh. J. S and Kashyap. A. K. (1999): Methane flux from irrigated rice fields in relation to crop growth and N- fertilization. Soil Biology and Biochemistry 31, 1219-1225.

Segers, R. (1998): Methane production and methane consumption: a review of processes underlying wetland methane fluxes. Biogeochemistry (41):23-51.

Soil survey staff (1962): Soil Survey Manual. USDA. Handbook, No. 18, Washington, D.C., UAS

Yao, Z.; Zheng, X.; Dong, H.; Wang, R.; Mei, B and Zhu, J. (2012): .A3-year record of $\mathrm{N}_{2} \mathrm{O}$ and $\mathrm{CH}_{4}$ emissions from a sandy loam paddy during rice seasons as affected by nitrogrn application rates. Agriculture, Ecosystems and Environment. (152):1-9.

Yang, S.S and Chang, H.L. (1998): Effect of environmental conditions on methane production and emission from paddy soil. Agri. Ecosyst. Environ. (69):69-80. 


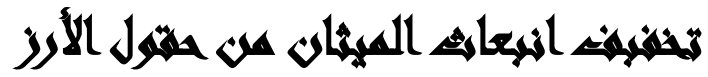

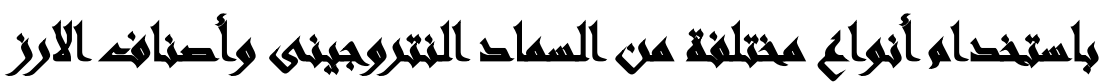

[0]

هشام إبراهيم القصاص(')- طه عبد العظيم محمد عبد الرازق(')- مسعد قطب قطب حسانين(ץ) حنان محسن سرور

( ) معهد الدراسات والبحوث البيئية، جامعة عين شمس r r) معهد بحوث المحاصيل الحقلية، مركز بحوث الزراعة

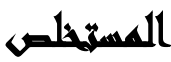

تم إجراء تجربة حقلية لدراسة تأثير انواع من الاسمدة النيتروجين واصناف من الأرز على انبعاث

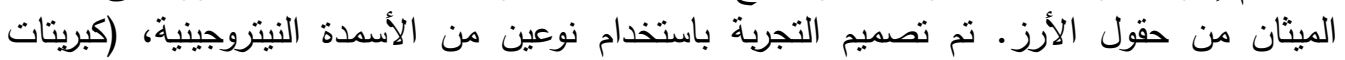

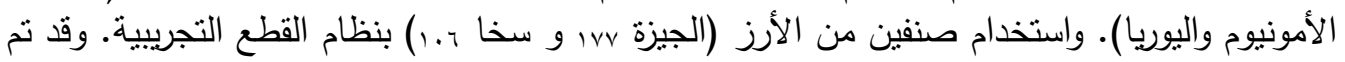

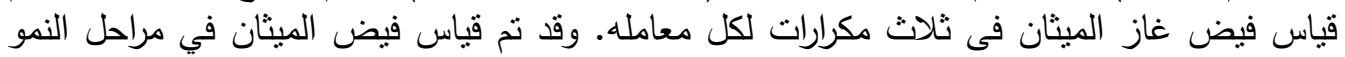

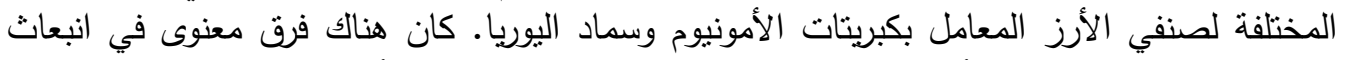

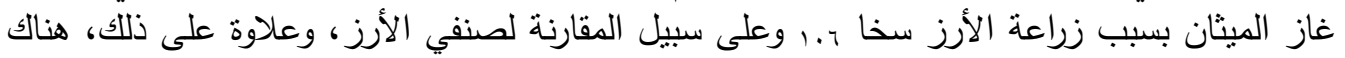

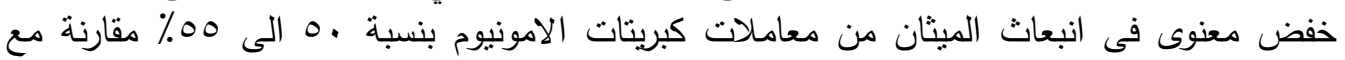

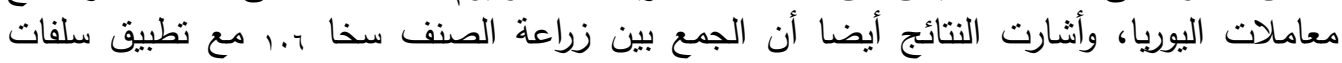

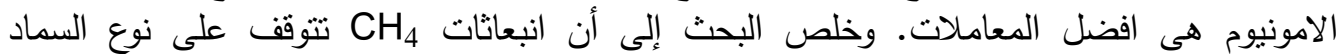
النتروجينى وصنف الأرز المستخدم فى التربة المصرية. 